\title{
10. The PPP phenomenon: performance and governance insights
}

\author{
Graeme Hodge and Carsten Greve
}

\section{Introduction}

Public-private partnerships (PPPs) have now attracted wide interest around the world. Few people, however, agree on what a PPP really is. While they are hailed as a new collaborative way to get the best of both sectors, the definition of PPPs remains cloudy, and performance assessments are hotly disputed. This chapter presents an academic examination of this form of collaboration and looks at the global evidence of performance. It articulates just what is new in Australia's PPPs and suggests governance reforms are needed in order to overcome the legitimacy concerns of citizens and parliaments.

The public-private debate has been an important thread in history, and there has always been some degree of public-sector and private-sector cooperation (Wettenhall 2003, 2005). The fact that 82 per cent of the 197 vessels in Sir Francis Drake's fleet, which successfully conquered the Spanish Armada in 1588, were private contractors to the Admiralty, ${ }^{1}$ Australia's long history of using private contractors for construction in huge infrastructure projects such as the Snowy Mountains Hydro-Electric Scheme, and the century-long partnership between the commercial company Falck (at one stage a part of the global company Group 4 Securicor) and the Danish public sector to deliver emergency services all attest to this. Other public-private cooperative ventures have included the successful Sydney Olympic Games and the construction of Europe's Channel Tunnel.

Viewing these arrangements as cooperative forms of partnership, however, brings with it good and bad news. On the one hand, it is true, for example, that privateer shipping underpinned the growth and dominance of the British global economic empire, and that private contracting saw the dream of the Channel Tunnel achieved. On the other hand, privateer shipping was a 'feeble and corrupt system' in which leading officials promoted partnership ventures intent on plunder, while the fragile financial position of the Channel Tunnel has now left citizens, governments and private investors with huge uncertainties. Little wonder, then, that arguments about efficiency, service quality and accountability in the two sectors have been well rehearsed.

\section{The PPP pedigree}

Scholars now view PPPs as a tool of governance, or else a 'language game' (Teisman and Klijn 2001, 2002). Turning first to partnerships as 'governance', 
two dimensions appear to be relevant: first, the financial arrangements between public and private actors; and second, the tightness of organisational linkages between the two actors (Hodge and Greve 2007). Formally, the Dutch public-management scholars van Ham and Koppenjan (2001:598) define a PPP through an institutional lens as 'co-operation of some sort of durability between public and private actors in which they jointly develop products and services and share risks, costs and resources which are connected with these products'. This definition emphasises durable cooperation and an equal sharing of risks and rewards in producing something jointly. This emphasis differs from the PPP notion regarding infrastructure projects, including build-own-transfer (BOT), build-own-operate-transfer (BOOT), as well as so-called sale-and-lease-back arrangements in which local governments sell their buildings and then rent them back from a financial organisation on a 20 or 30-year contract. Many other interpretations of PPPs as financial and organisational arrangements are also possible, involving at least five families of arrangements: ${ }^{2}$

- institutional cooperation for joint production and risk sharing - for example, the Netherlands Port Authority (van Ham and Koppenjan 2001, 2002; Klijn and Teisman 2005)

- long-term infrastructure contracts, which emphasise tight specification of outputs in long-term legal contracts - as exemplified in the United Kingdom (Osborne 2001b; Savas 2000; Berg et al. 2002; Perrot and Chatelus 2000; Ghobadian et al. 2004; Grimsey and Lewis 2004)

- public-policy networks, in which loose stakeholder relationships are emphasised (Vaillancourt Rosenau 2000)

- civil-society and community development, in which the partnership symbolism is adopted for cultural change, as in Hungary and Europe (Osborne 2001a)

- urban renewal and downtown economic development - where, in the United States, a portfolio of local economic development and urban regrowth measures is pursued (Osborne 2001a; Bovaird 2004).

These PPP families cover a wide array of different governance types and are clearly more than just the private finance initiative (PFI) experience of the United Kingdom or the current infrastructure-contracting practices of Australia.

The alternative view of PPPs is as a language game. Linder (1999) noted the 'multiple grammars' of PPPs, with governments avoiding the terms 'privatisation' or 'contracting out' in favour of speaking about 'partnerships'. This word presents a warmer and friendlier proposition than previous, more pejorative terms. It has also provided public managers with an opportunity to adopt a new buzz word or even reframe existing policies under a catchier name.

The language question is an issue of some significance, as it frames our local understanding of partnerships. Of course, language games are at the heart of all 
public-policy debates. Such language games in the PPP arena can, however, lead to the amusing situation in which two governments on opposite sides of the globe see PFI-type PPPs in opposite ways. Look, for example, at the long-term infrastructure-contract family of PPPs. In Victoria, Australia, such PPPs are argued as being nothing to do with privatisation and are vigorously separated from this policy. In the United Kingdom, however, the Department of Treasury and Finance sees the two as inherently connected and speaks of PPPs as being directly equivalent to privatisation (HM Treasury 2003). In other words, the same PPP phenomenon is being framed in two opposite ways for local political gain.

Another example of this language game is the very label 'partnership' for large private finance contracts. This is nonsense. Infrastructure finance deals are no more partnerships than the contract made when citizens take out a house mortgage with their local bank. Public-policy language games are again being used to suit local political objectives and obscure meanings rather than to clarify and sharpen our understanding of the partnership phenomenon.

So PPPs are a broad church of many families, and it is not a simple matter to judge whether they are the next chapter in the privatisation story, another promise in our continuing attempts to better define and measure public-sector service performance, ${ }^{3}$ a renewed support scheme for boosting business in difficult times, or a language game camouflaging the next frontier of conquering transaction merchants, legal advisors and bankers pursuing fat commissions.

\section{Evaluating PPP performance}

Several Australian states have followed the United Kingdom and, led by Victoria, have proceeded down the road of defining PPPs in terms of the PFI- that is, as a business relationship, underpinned by a long-term contract, often with private financing, for the delivery of maintenance and the operation of infrastructure and services, ${ }^{4}$ involving large cash flows, the capacity to shift risks and rewards and potential for joint decision making.

How might we evaluate this PPP family member? There have been no meta-analyses or statistical reviews of PPP performance to date. The complexity of evaluating infrastructure arrangements is compounded by the observation that there is a wide variety of contractual and institutional options, the adoption of either public or private up-front finance and potential application across many policy areas such as transport, water, prisons, education, social and emergency services. Also critical here is the observation that we all come to such an evaluation with our own individual criteria for assessment. ${ }^{5}$ Those involved directly in the financial transactions, not surprisingly, often speak highly of them. Of more relevance here, however, is our evaluation of PPPs against the stated objectives of PPP delivery by governments and broader policy promises 
being made to citizens. So, should we look at policy rhetoric, the legal contract or historical outcomes to discern partnership success (Hodge 2004b)? These outcomes vary from the weakest evidence of success at the policy rhetoric end to the strongest at the historical outcomes end.

There has been much rhetorical assessment, including colourful salesmanship and praise on the one hand, and stinging criticism on the other. PPPs are thus characterised in terms of 'yet again screwing the taxpayer', with private sponsors as 'evil bandits running away with all the loot' and as 'Problem, Problem, Problem' (Hodge and Greve 2007). The other side of the rhetoric has seen PPPs as a 'marriage made in heaven' with continued loud advocacy. Little, however, is resolved. While some analyses of contract arrangements are now available, the jury is still out given the long-term nature of these contracts. ${ }^{6}$ How, then, have PFI-type PPPs performed according to the historical evidence of outcomes? We ought to base our analysis on the underlying objectives of PPPs. Under John Major's government in the United Kingdom, the initial rationale was to get around formal public-sector debt levels. Private financing promised a way to provide infrastructure without increasing the public-sector borrowing ratio (PSBR). This was followed by the promise that PPPs would reduce pressure on public-sector budgets. Neither the availability of off-budget financing nor avoiding accountability for capital funding are, however, particularly valid criteria on which to evaluate PPPs. A mechanism though which governments can turn a large, one-off capital expenditure into a series of smaller, annualised expenditures has simply been provided. Like any domestic credit card or mortgage arrangement, however, this does not reduce pressure on the family budget, because all debts must be repaid in the end. ${ }^{7}$

The third promise of PPPs - and one with more bite to it - is that this delivery mechanism provides better value for money for taxpayers. This is a policy promise worthy of examination. Added to these promises was the implicit ethos of better accountability, improved business confidence, better on-time and on-budget delivery, as well as greater innovation. What is evident, then, is that there have been eight separate justifications for PPPs, which have altered over time and even today remain somewhat slippery.

What does the more serious evidence of the veracity of these claims say? There is a wide canvas, so we will focus only on a small number of representative evaluation findings. Looking now at the third of these eight promises - the claim of better value for money - how does the international evidence stack up?

\section{Evidence of value for money}

Early prominent estimates of efficiencies to be gained through PPPs included cost-savings figures of 17 per cent from Arthur Anderson and LSE Enterprise in their analysis of 29 business cases, 10-20 per cent based on seven empirical 
cases from the National Audit Office (2000) and 10-30 per cent (Shepherd 2000). Savings in these business cases were due mainly to the calculus of risk transfers assumed from the public to the private sector. The later analysis of Pollitt (2002) also summarised the findings of the National Audit Office and showed that in a sample of 10 major PFI case evaluations undertaken, the best deal was probably obtained in every case, and good value for money was probably achieved in eight of the 10 cases.

At the other extreme, the early evidence on (PFI) PPP effectiveness is not as pretty. From the United Kingdom, authors such as Pollock et al. (2002) and Shaoul (2004) have been highly critical of PFI arrangements across a wide range of services, including roads, hospitals and rail-transport infrastructure. Likewise, Monbiot (2002) launched a very public attack through the Guardian newspaper, labelling PPPs as 'public fraud and false accounting...commissioned and directed by the Treasury'. US commentators such as Bloomfield et al. (1998) found a Massachusetts correctional facility was 7.4 per cent more expensive through lease purchase financing than with conventional financing, with the real costs and risks camouflaged from the public. In Europe, Greve (2003) characterised the Farum PPP as 'the most spectacular scandal in the history of Danish Public Administration', resulting in raised taxes for the citizens of Farum, higher debt for its local government and a former mayor on trial in the courts. Australian PPP analyses such as Walker and Con Walker (2000) saw off-balance-sheet PPP infrastructure financing deals as 'misleading accounting trickery', which eroded accountability to parliament and to the public. In support, they cited private project consortium real rates of return, which were 10 times those expected for the public for the proposed metropolitan Sydney and Mascot Airport and Sydney's M2 Motorway (Walker and Con Walker 2000:204). ${ }^{8}$

Evidence continues to be mixed. At the positive end, Pollitt (2005) has shown not only the popularity of PFI - with the UK Government typically raising some 15-20 per cent of its capital budget each year through this mechanism ${ }^{9}$ - but, through five case studies, its empirical success, notwithstanding the lengthy and costly bidding process among a small number of bidders and high-profile problems with individual PFI projects. He argues that compared with what might have happened under conventional public procurement, projects under PFI are now 'delivered on time and to budget a significantly higher percentage of the time', with construction risks 'generally transferred successfully' and with 'considerable design innovation'. Importantly, while Pollitt acknowledges that it is possible that many of the assumed benefits of PFI projects are hypothetically available through conventional procurement, the reality is that these would not be achieved without the learning and leverage provided through the PFI initiative. 
Likewise, Mott Macdonald (2002) and the National Audit Office (2003) report PPPs as being delivered on time far more often than traditional infrastructure provision arrangements. ${ }^{10}$ They found, impressively, that whereas traditional 'public' infrastructure provision arrangements were on time and on budget 30 per cent and 27 per cent of the time, PFI-type partnerships were on time and on budget 76 per cent and 78 per cent of the time, respectively. In Australia meanwhile, the Audit Office of New South Wales found 'persuasive' the business case for two PFI contracts to build 19 schools, at between 7 to 23 per cent cheaper than the traditional alternative (Auditor-General of New South Wales 2006). The Allen Consulting Group (2007), in a project funded by Australia's infrastructure suppliers, reported PPPs as being an 11 per cent cheaper alternative to traditional projects based on a sample of 54 projects.

In striking contrast is Shaoul's evidence from the United Kingdom. Countering the government's rationale, itself described as an 'ideological morass', she presents a litany of failed PFI project examples and reveals a value-for-money appraisal methodology biased in favour of policy expansion, a pitiful availability of information needed for project evaluation and scrutiny and projects in which the value-for-money case rested almost entirely on risk transfer but for which, strangely, the amount of risk transferred was almost exactly what was needed to tip the balance in favour of undertaking the PFI mechanism. Added to this apparent manipulation of the public sector comparator (PSC) process were the observations that in hospitals and schools 'the PFI tail wags the planning dog' with projects changed to make them 'more PFI-able', highly profitable investments being engineered for private companies with 'a post tax return on shareholders' funds of 86 per cent', several refinancing scandals and conspicuously unsuccessful IT projects and risk-transfer arrangements that in reality meant that risks had not been transferred to the private sector at all but had been borne by the public. Not surprisingly, Shaoul (2005) concludes that at best, PFI has turned out to be very expensive with, moreover, a lack of accountability leading to difficulty in learning from past experiences. Partnerships, in her view, are 'policies that enrich the few at the expense of the majority and for which no democratic mandate can be secured'.

Added to this criticism is the first peer review of the impressive on-time and on-budget figures reported by Mott Macdonald (2002). The review of Pollock et al. (2007) was unequivocal in its judgment of these figures, stating 'there is no evidence to support the Treasury cost and time overrun claims of improved efficiency in PFI'. The estimates being quoted were 'not evidence based but biased to favor PFI' and 'only one study compares PFI procurement performance, and all claims based on [this] are misleading'.

Other evidence lies between these extremes. Boardman et al. (2005), for instance, noted the difficulty of capturing transaction costs in any comparison of 
partnership and traditional project delivery and catalogued 76 major North American PPP projects. They noted that less than half included a significant private financing role. They presented five transport, water provision and waste projects, showcasing a series of 'imperfect' partnership projects with high complexity, high asset specificity, a lack of public-sector contract management skills and a tendency for governments to be unwilling to 'pull the pin' on projects once under way. They point particularly to private entities being 'adept at making sure, one way or another, that they are fully compensated for risk-taking', and to strategic behaviour such as declaring bankruptcy (or threatening to) in order to avoid large losses. There are clear tensions for governments here, having to hold their nerve and watch commercial failures materialise when risks are borne by the private sector, despite their yearning to be viewed as successfully governing a growing and vibrant market.

Similarly, English (2005) documents the failure of the Latrobe Regional Hospital case in Victoria and provides a reminder of the importance and the difficulty of value-for-money estimates. A 20-year BOO project, this arrangement failed only two years into the contract due to a commercial failure to understand the case-mix funding model as well as because of ineligibility for additional top-up funding. Importantly, English also notes that amid the appearance of full disclosure by the state government, crucial documentation in terms of PSC calculation and financial arrangements underpinning the PPPs was withheld from citizens, even after freedom-of-information requests. Imperfect PPP arrangements, indeed. The Auditor-General's line in reviewing this situation was also interesting - apparently seeing this case not only as a financial failure of the private hospital, but as a governance failure by government. English shows that the government had not behaved as an intelligent and informed buyer. It had accepted an unsustainable price bid in the first place, had not undertaken any comparative analysis to benchmark public provision and had not recognised that the government was unable, in reality, to transfer the social responsibility of hospital provision. ${ }^{11}$

Hodge (2005) listed 48 Australasian projects and observed that while commercial risks could have been largely well managed, the same success could not be claimed for the governance dimension. Of real importance here was evidence from eight PPP case studies in Victoria examined by Fitzgerald (2004). Two crucial observations were made.

First, the superiority of the economic-partnership mode over traditional delivery mechanisms was dependent on the discount rate adopted in the analysis. Indeed, opposite conclusions were reached when using an 8.65 per cent discount rate at one extreme (leading to the conclusion that the PPP mechanism was 9 per cent cheaper than traditional delivery) compared with an evaluation adopting a 5.7 
per cent discount rate (where the PPP mechanism was apparently 6 per cent more expensive).

Second, Hodge (2005) also made the point that government had clearly moved from its traditional stewardship role to a louder policy-advocacy role. As a consequence of this, we might reflect that government now finds itself in the middle of multiple conflicts of interest, acting in the roles of policy advocate, economic developer, steward for public funds, elected representative for decision making, regulator of the contract life, commercial signatory to the contract and planner. Far more debate is now needed to discuss the optimum ways in which long-term public interests can best be protected and nurtured in the light of experience, particularly noting citizen concerns about low PPP transparency and high deal complexity as well as criticism of lack of competition in these deals. $^{12}$ In other words, in addition to scepticism about the value for money provided by PPPs, their governance seems to have been a weakness to date.

Boardman et al. (2005) from North America and Hodge (2005) from Australia conclude independently that 'caveat emptor' is the most appropriate philosophy for governments to take as we move forward with infrastructure PPPs. Learning from the global empirical experience counters the notion that 'all the evidence that I have ever read on PPPs has been positive', as recently argued by one Australasian state government minister advocating billions of more dollars in partnership investments.

Overall, it would be fair to observe that citizens have been somewhat sceptical of the political promises made for PFI-type PPPs. ${ }^{13}$ This is hardly surprising. History provides us with plenty of examples of governments ideologically bent on applying the latest fashionable policy prescription when neither was the patient ill, nor the policy at all effective. Moreover, a range of examples, from supplying electricity in Manila ${ }^{14}$ and the London Underground rail-transport debacle $^{15}$ to a similar recent partnership farce with Sydney's Cross-City Tunnel (Davies and Moore 2005), shows that government reforms undertaken in the name of 'partnership' can easily go wrong for a host of reasons.

As well as this evidence for and against PPPs, the question of the counterfactual is also crucial here. On the one hand, the question of the exact 'alternative' against which private finance schemes are assessed is often left cloudy. We are left uncertain about whether the alternative is the old public works department with its in-house team is assumed, or the use of competitive tendering arrangements for private contactors (already in regular use in many jurisdictions), or some other public, private or mixed arrangement. The precise details of financing are also usually unclear. On the other hand, historical empirical experience also reminds us that the London Underground (under public ownership) has had a history of completing investment projects over budget and late with, for instance, line upgrades for the Jubilee Line six years late and 
30 per cent over budget, and an analysis of some 250 projects by London Underground between 1997 and 2000 revealing cost overruns averaging 20 per cent.

What might we make of all this? It seems, overall, that the economic and financial benefits of PPPs are still subject to debate and, hence, considerable uncertainty.

We noted earlier that our evaluation should include an assessment of PPP governance. There is much that might be discussed here, but before we contemplate this arena, we ought first to articulate just what is, if anything, new with Australia's trend towards PFI-type PPP arrangements.

\section{What is new with Australia's PPPs?}

In terms of providing essential public infrastructure or services through history, there is much in today's debates that is not new. Governments have always made sensitive decisions resulting in the provision of essential large-scale public infrastructure. Such decisions have often had huge, long-term financial implications. Likewise, governments have for many years employed private contractors to undertake works and services, and competitive bidding for construction contracts by private companies has been around now for decades. The PPP phenomenon ought not therefore be misconstrued as a public versus private debate or a debate about the merits of infrastructure provision. We have centuries of experience accumulated in both of these arenas, although too often this point goes unacknowledged.

There do, however, appear to be three elements that are new in Australia's PFI model of partnership:

- the preferential use of private finance arrangements

- the highly complex contractualisation of 'bundled' infrastructure arrangements

- altered governance and accountability assumptions.

Importantly, the first two new aspects of infrastructure provision-those of private finance and increased contractual complexity - have major implications for the third: governance and accountability arrangements. How well, then, do PPPs perform on these dimensions?

\section{Governance evidence}

The availability of private finance for major infrastructure projects has essentially given governments a new capacity to use a 'mega credit card' with which to sign up to infrastructure deals. These deals can be consummated through the development of large legal contracts in which projects are purchased, as if 'off the shelf'. The political incentives for government have been high: quicker promised delivery of infrastructure and more positive relationships with finance 
and construction businesses. These incentives have also been closely aligned with incentives for the finance industry in terms of continued business transactions, new financial deals and perhaps even policy influence and project selection priority. Each of these three dimensions deserves careful deliberation in terms of governance. For each, we also should ask what the implications are in terms of democratic legitimacy.

\section{Preference for private finance}

While in concept PPPs are not strictly dependent on the provision of private finance, the reality in Australia is that in leading jurisdictions such as Victoria, PPP activities rely almost completely on the provision of initial private finance. As we noted extensively above, however, private finance arrangements appear to come at a premium for the life of the project, and the veracity of the claim that PPPs lead to better value for money for citizens is, at best, highly contestable. In addition to the international evidence of value for money, Victoria's Fitzgerald Review estimated that Victoria's citizens had probably already paid about \$A350 million more than needed for the eight Victorian projects (totalling \$2.7 billion) it reviewed. Limited transparency and complex adjustment formulae for partnership financial arrangements do not give citizens confidence in the arrangements when, despite the rhetoric of risk sharing with private financing, a significant financial role for government is nevertheless often the reality.

To concerns about value for money and risks can be added the criticism that in the United Kingdom the PSC has been manipulated and planning processes have been reshaped to ensure that projects were 'more PFI-able' to access capital funds. The implications for democratic legitimacy of such matters are profound.

\section{Complexity}

The second important characteristic of Australia's PPPs has been the complexity of partnership contract deals. Of course, greater complexity was introduced through more adventurous project-management mechanisms through the 1990s before PPPs. The need for extensive legal and other contractual documentation for all financial flows and relationships between multiple parties alone is, however, a direct characteristic of the partnership phenomenon (Evans and Bowman 2005).

Complexity, however, is not simply a matter of narrow legal project concerns. It has been rare to find members of parliamentary committees who have themselves personally understood the deals being done. In states such as Victoria, there are not even any parliamentary committees overseeing such infrastructure deals. Worryingly, ministers appear to have been supporting these deals on trust. Citizens also cannot get a clear picture of their worth underneath either the veil of complexity or the cloak of 'commercial in confidence'. To date, few independent parliamentary-level reviews have been able to break through this 
veil. A further factor here is the need for the State to have the administrative and the intellectual capacity to understand these deals, to monitor them as they operate and to manage them as they evolve with time.

Perhaps the real issue in terms of democratic legitimacy is not the matter of complexity itself, but how complexity is handled through political and democratic processes. Public-policy decision making in government by its nature deals with multiple complex issues ranging from stem-cell research and IT privacy to intricate matters of national economic and financial importance. The real question here is whether complexity is addressed by ensuring that improved accessibility mechanisms for citizens are created or, alternatively, whether what is created is a shield behind which governments can shelter and avoid accountability. Media reports that the Victorian Government delayed numerous requests for information on PPPs that could have damaged its re-election prospects certainly do not sit well with claims that PPP arrangements are sufficiently transparent to assure legitimacy (Dowling 2006; Tomazin 2006).

\section{Accountability and governance arrangements}

PPPs encompass different accountability and governance arrangements compared with traditional procurement - indeed, these arrangements are one of the claimed advantages of this provision method. Interlinked financial incentives across a consortium of players, the sharing of risks through carefully contractualised legal relationships and more flexible decision-making processes between executive government and service providers all feature as improvements on traditional procurement arrangements. Moreover, the progressive contractualisation of the State's services and activities has been accompanied by the general assumption of increased accountability in all its forms, although this has rarely been tested. While contractualisation could have increased managerial accountability, it could have been at the expense of reduced public accountability in its various forms.

Also, while we have instituted a 'regulatory state' of independent regulators, ombudsmen and audit review bodies in order to disperse power away from political quarters after the privatisation of state businesses, this has not yet occurred with PPP deals. They have continued to be essentially two-way government-business deals rather than also involving the community or any other independent accountability body to protect the public's interests. They have also been handled on a case-by-case basis, by the government itself, in the face of multiple conflicts of interest. The potential for the interests of the advocating government and business partners to dominate the public interest is palpable here. Indeed, early drafts of Victoria's PPP guideline materials did not even mention the 'public interest' notion and treated government solely as if it were a contractual partner in a commercial deal. This is reminiscent of past centuries. $^{16}$ 
Clearly, communities need far more discussion and debate about how we might better ensure that the public interest is met through PPP deals, as well as meeting the needs of the contracting parties. To the extent that new infrastructure contract-delivery arrangements have reduced existing accountability arrangements and altered longstanding governance assumptions without democratic debate, new partnership arrangements lack legitimacy (Hodge 2006).

Are such concerns just an academic obsession with an imperfect world? Three recent Australian parliamentary inquiries suggest that such concerns about PPP governance are justified and have profound implications.

\section{Parliamentary inquiry findings}

The findings of two recent high-level PPP reviews in New South Wales and Victoria $^{17}$ are striking. First, some 35 of the 46 recommendations of these two reports relate to these three governance concerns - that is, private finance preference, financial complexity, and accountability and governance matters. In other words, some 76 per cent of the changes recommended by our recent parliamentary committees have concerned these issues of governance. Second, the largest two categories of these recommendations dealt with PPP accountability and governance, and the implications of the private finance preference. Third, there is a remarkable consistency between the tone of recommendations made by the committees and the concerns expressed in this chapter. Examples of inquiry recommendations illustrating this point include recommendations for three-page summaries of contract deals and value-for-money reports, better post-implementation evaluations and audits, stronger parliamentary oversight, more precise definition of the traditional options considered and improved knowledge of discount rates.

Crucially, the very existence of these parliamentary inquiries (as well as the additional parliamentary inquiry into Sydney's Cross-City Tunnel project) is a testament to the degree to which the current legitimacy of Australian PPPs is questionable. Discussions about the legitimacy of PPPs have also moved from the cabinet table and banking boardrooms into the supermarkets and the homes of citizens through the daily media. In terms of taxpayers' interests, Tomazin (2006), for instance, stated that 'State Government secrecy surrounding billions of dollars' worth of projects done in partnership with the private sector means Victorians have no idea whether they provide value for money'. Moreover, Tomazin was concerned with 'the lock-in effect of long-term contracts [which] might have an effect on the decision making capacity of future governments'. Furthermore, traditional ministerial accountability mechanisms failed palpably when the premier and ministers of the NSW Government refused to attend the Cross City Tunnel Parliamentary Committee to explain their perspectives. ${ }^{18}$ The illegitimacy of one government being happy to sign up the next dozen governments to multi-billion-dollar contract payments with subsequent elected 
representatives then not participating in a fundamental public-accountability mechanism to explain decisions marks an all-time low in our traditional democratic polity. Indeed, the fact that a significant amount of performance material was omitted from the final inquiry document in Victoria (if we believe leaks reported in the daily newspaper at the time; Tomazin 2006) suggests that there continues to be much need for legitimacy-based reforms to be instituted. The omitted information on the specific performance of PPPs in Victoria appears to have been most embarrassing for the Kennett-Stockdale state government and its ministers and the subsequent Bracks-Brumby state government. It could even be that a coalition of political interests and business interests has existed against the interests of truthful revelations to citizens.

Such sinister logic aside, there nonetheless continues to be an obvious broader confluence of interests between political interests - enjoying better party funding for elections, potentially earlier delivery of big infrastructure projects and other parties to use as scapegoats should anything go awry - and the private interests of financiers, consulting firms, advisors and infrastructure companies. This suggests that PPPs could well continue for some time yet. Having said this, the future legitimacy of PPPs will depend on the ways in which the partnership phenomenon can be reformed and these current value-for-money and governance deficits overcome.

\section{Conclusions}

The partnership ideal has a long historical pedigree. Since partnerships have always come with good and bad news, care is, however, needed in their evaluation. All assessments need to be reported, not just those results supporting one's own views. There is a huge diversity in PPP approaches around the globe today. The contemporary phenomenon of private finance-dominated partnership arrangements in Australia is one important family group.

Multiple goals have been claimed for long-term infrastructure contract-type PPPs. Looking simply at the question of value for money, there is a wide range of mixed evidence. This has gone largely unacknowledged to date. In other words, there is little doubt in terms of successes and failures that some of the glowing policy promises of PPPs have been delivered. Equally, however, evaluations of such arrangements have provided contradictory evidence of value-for-money effectiveness. A further concern surrounds PPPs in terms of governance failures. Contracts can shield governments from accountability rather than enhancing it. Also, treasuries of advocating governments act with multiple conflicts of interest and are free of any independent regulator charged with protecting the public's interest. As a consequence, Australian PPPs currently lack legitimacy. 
These findings are important in the midst of ideological blind spots being experienced by many PPP advocates, such as central treasury departments, who seem more intent on policy advocacy than on questions of stewardship. Governments ought operate more often with a philosophy of caveat emptor, and need now to address the significant governance shortfalls identified. PPPs promise much. Careful evaluation of who gets the biggest rewards from these schemes is, however, now needed to ensure that governments maintain their intelligence on policy effectiveness.

\section{References}

Allen Consulting Group 2007, Performance of PPPs and Traditional Procurement in Australia, Final Report to Infrastructure Partnerships Australia, 30 November 2007.

Arthur Anderson and LSE Enterprise 2000, Value for Money Drivers in the Private Finance Initiative, UK Treasury Task Force, London.

Auditor-General of New South Wales 2006, The New Schools Privately Financed Project, Auditor-General's Report Performance Audit, March, Sydney.

Berg, Sanford, Pollitt, Michael and Tsuji, Masatsugu (eds) 2002, Private Initiatives in Infrastructure: Priorities, incentives and performance, Edward Elgar, Aldershot.

Bloomfield, Pamela, Westerling, David and Carey, Robert 1998, 'Innovation and risks in a public-private partnership: financing and construction of a capital project in Massachusetts', Public Productivity and Review, vol. 21, no. 4, pp. 460-71.

Boardman, Anthony, Poschmann, Finn and Vining, Aidan 2005, 'North American infrastructure P3s: examples and lessons learned', in Graeme Hodge and Carsten Greve (eds), The Challenge of Public-Private Partnerships: Learning from international experience, Edward Elgar, Cheltenham, pp. 162-89.

Bovaird, Tony 2004, 'Public-private partnerships in Western Europe and the US: new growths from old roots', in Abby Ghobadian, David Gallear, Nicholas O'Regan and Howard Viney, Public-Private Partnerships: Policy and experience, London, pp. 221-50.

Davies, Anne and Moore, Matthew 2005, 'Cross City Tunnel deal: the whole bloody thing will be made public', Sydney Morning Herald, 19 October.

Department of Treasury and Finance 2001, Partnerships Victoria: Risk allocation and contractual issues, State Government of Victoria, Melbourne.

Dowling, Jason 2006, 'Bracks' secret state', Age, 24 September. 
The Economist 2002, 'Enron-on-Thames: Railtrack and British public finance', The Economist, 30 March.

Edwards, Pam, Shaoul, Jean, Stafford, Anne and Arblaster, Lorna 2004, Evaluating the Operation of PFI in Roads and Hospitals, Certified Accountants Education Trust, London.

English, Linda 2005, 'Using public-private partnerships to deliver social infrastructure: the Australian experience', in Graeme Hodge and Carsten Greve (eds), The Challenge of Public-Private Partnerships: Learning from international experience, Edward Elgar, Cheltenham, pp. 290-304.

Evans, Joanne and Bowman, Diana 2005, 'Getting the contract right', in Graeme Hodge and Carsten Greve (eds), The Challenge of Public-Private Partnerships: Learning from international experience, Edward Elgar, Cheltenham, pp. 62-80.

Fitzgerald, Peter 2004, Review of Partnerships Victoria Provided Infrastructure, Growth Solutions Group, Melbourne.

Greve, Carsten 2003, When public-private partnerships fail: the extreme case of the NPM-inspired local government of Farum in Denmark, Paper for EGPA Conference, 3-6 September, Oerias, Portugal.

Ghobadian, Abby, Gallear, David, O'Regan, Nicholas and Viney, Howard 2004, Public-Private Partnerships: Policy and experience, London.

Grimsey, Darren and Lewis, Mervyn 2004, Public-Private Partnerships: The worldwide revolution in infrastructure provision and project finance, Edward Elgar, Cheltenham.

HM Treasury 2003, PFI: Meeting the investment challenge, The Stationery Office, London.

Hodge, Graeme 2004a, 'Conclusion', in Graeme Hodge, Valerie Sands, David Haywood and David Scott (eds), Power Progress: An audit of Australia's electricity reform experiment, Australian Scholarly Publishing, Melbourne.

Hodge, Graeme 2004b, 'Risks in public-private partnerships: shifting, sharing or shirking?', Asia Pacific Journal of Public Administration, vol. 26, no. 2, pp. 157-79.

Hodge, Graeme 2004c, 'The risky business of public-private partnerships', Australian Journal of Public Administration, vol. 63, no. 4, pp. 37-49.

Hodge, Graeme 2005, 'Public-private partnerships: the Australian experience with physical infrastructure', in Graeme Hodge and Carsten Greve (eds), The Challenge of Public-Private Partnerships: Learning from international experience, Edward Elgar, Cheltenham, pp. 305-31. 
Hodge, Graeme 2006, 'Public-private partnerships and legitimacy', University of New South Wales Law Journal, Forum, vol. 12, no. 2, November.

Hodge, Graeme and Greve, Carsten (eds) 2005, The Challenge of Public-Private Partnerships: Learning from international experience, Edward Elgar, Cheltenham.

Hodge, Graeme and Greve, Carsten 2007, 'Public-private partnerships: an international performance review', Public Administration Review, June.

Klijn, Erik-Hans and Teisman, Geert 2005, 'Public-private partnerships as the management of co-production: strategic and institutional obstacles in a difficult marriage', in Graeme Hodge and Carsten Greve (eds), The Challenge of Public-Private Partnerships: Learning from international experience, Edward Elgar, Cheltenham, pp. 95-116.

Linder, Stephen 1999, 'Coming to terms with the public-private partnership: a grammar of multiple meanings', American Behavioural Scientist, vol. 43, no. 1, pp. 35-51.

McIntosh, Kylie, Shauness, Jason and Wettenhall, Roger 1997, Contracting Out in Australia: An indicative history, Centre for Research in Public Sector Management, University of Canberra, Canberra.

Monbiot, George 2002, 'Health - a challenge to the Chancellor: refute these charges, or admit that the private finance initiative is built on fraud and false accounting', Guardian, 18 June.

Mott Macdonald 2002, Review of Large Public Procurement in the UK, Mott Macdonald, London.

National Audit Office 2000, Examining the Value for Money of Deals Under the Private Finance Initiative, The Stationery Office, London.

National Audit Office 2003, PFI: Construction Performance, HC 371, The Stationery Office, London.

Osborne, Stephen 2001a, 'Introduction: understanding public-private partnerships in international perspective: globally convergent or nationally divergent phenomena?', in Stephen Osborne (ed.), Public-Private Partnerships: Theory and practice in international perspective, Routledge, New York.

Osborne, Stephen (ed.) 2001b, Public-Private Partnerships: Theory and practice in international perspective, Routledge, New York.

Perrot, Jean-Yves and Chatelus, Gautier (eds) 2000, Financing of Major Infrastructure and Public Service Projects: Public private partnerships, lessons from French experience throughout the world, Presses de l'Ecole Nationale des Ponts et Chaussées, Paris. 
Pollitt, Michael 2002, 'The declining role of the State in infrastructure investment in the UK', in Sanford Berg, Michael Pollitt and Masatsugu Tsuji (eds), Private Initiatives in Infrastructure: Priorities, incentives and performance, Edward Elgar, Aldershot.

Pollitt, Michael 2005, 'Learning from the UK private finance initiative experience', in Graeme Hodge and Carsten Greve (eds), The Challenge of Public-Private Partnerships: Learning from international experience, Edward Elgar, Cheltenham, pp. 207-30.

Pollock, Allyson, Price, David and Player, Stewart 2007, 'An examination of the UK Treasury's evidence base for cost and time overrun data in UK value-for-money policy and appraisal', Public Money and Management, April, pp. 127-33.

Pollock, Allyson, Shaoul, Jean and Vickers, Neil 2002, 'Private finance and value for money in NHS hospitals: a policy in search of a rationale?', British Medical Journal, vol. 324, pp. 1205-8.

Savas, Emanuel Steve 2000, Privatization and Public-Private Partnerships, Chatham House Publishers and Seven Bridges Press, New York.

Shaoul, Jean 2004, 'Railpolitik: the financial realities of operating Britain's national railways', Public Money and Management, vol. 24, no. 1, pp. 27-36.

Shaoul, Jean 2005, 'The private finance initiative or the public funding of private profit', in Graeme Hodge and Carsten Greve (eds), The Challenge of Public-Private Partnerships: Learning from international experience, Edward Elgar, Cheltenham, pp. 190-206.

Shepherd, Tony 2000, A practitioner's perspective, Presentation to the Productivity Commission Workshop on Private Sector Involvement in Provision of Public Infrastructure, 12-13 October, Melbourne.

Teisman, Geert and Klijn, Erik-Hans 2001, 'Public-private partnerships in the European Union: official suspect, embraced in daily practice', in Stephen Osborne (ed.), Public-Private Partnerships: Theory and practice in international perspective, Routledge, New York, pp. 165-86.

Teisman, Geert and Klijn, Erik-Hans 2002, 'Partnership arrangements: governmental rhetoric or governance scheme?', Public Administration Review, vol. 62, no. 2, pp. 197-205.

Tomazin, Farrah 2006, 'Secrecy shields Bracks' deals from scrutiny', Age, 5 October.

Vaillancourt Rosenau, Pauline (ed.) 2000, Public-Private Policy Partnerships, MIT Press, Cambridge, Mass. 
van Ham, J. C. and Koppenjan, Joop 2001, 'Building public-private partnerships: assessing and managing risks in port development', Public Management Review, vol. 4, no. 1, pp. 593-616.

van Ham, J. C. and Koppenjan, J. F.M. 2002, Partnerships passing in the night?, IRSPM 5, 8-10 April, Edinburgh.

Walker, Bob and Con Walker, Betty 2000, Privatisation: Sell off or sell out? The Australian experience, ABC Books, Sydney.

Wettenhall, Roger 2003, 'The rhetoric and reality of public-private partnerships', Public Organisation Review: A Global Journal, vol. 3, pp. 77-107.

Wettenhall, Roger 2005, 'The public-private interface: surveying the history', in Graeme Hodge and Carsten Greve (eds), The Challenge of Public-Private Partnerships: Learning from international experience, Edward Elgar, Cheltenham, p. 43.

Williamson, Oliver 1985, The Economic Institutions of Capitalism, Free Press, New York.

\section{ENDNOTES}

${ }^{1}$ See Wettenhall (2003), who comments that cooperative public-sector activities go back centuries and that 'there is nothing new about the mixing of public-private endeavours... whatever the new enthusiasts may think'.

2 See Hodge and Greve (2007) for the details of these family members.

3 The recent history of the public sector internationally has been replete with schemes aiming to better define public-sector services and measure performance. Examples of such schemes have included but are not limited to: performance indicators and targets, management by objectives, total quality management, benchmarking, contracting and outsourcing, systems analysis, zero-based budgeting, performance budgeting, output-based budgeting, results budgeting, program budgeting, program planning and budgeting systems, competitive tendering and best value in local government. While benefits have no doubt been delivered through many of these initiatives, most have also fallen well short of the promises made.

4 Also crucial is the observation that no reviews to date have covered the political science/public policy/public administration literature (for example, Hodge and Greve 2007) and the economics/engineering literature (for example, Grimsey and Lewis 2004).

5 One project leader explained recently that because these new PPP arrangements enabled \$1 billion to be spent on infrastructure in the coming year compared with only $\$ 130$ million in the previous 12 months, the new arrangements were therefore some eight times better than the old. This personal criterion is understandable and might be mirrored by others involved in these transactions, including financiers, engineers, consultants and lawyers, but it has limited relevance for the broader community. 6 See Hodge (2004) for one such analysis.

7 The one important exception to this is the case in which a government enters an infrastructure deal requiring users or citizens to pay directly, such as tolls on a new road. Here, such an arrangement does reduce pressure on public-sector budgets, because government has essentially purchased the

infrastructure through the commitment of funds from future (private) road users rather than using its own resources.

8 These authors nevertheless concede that 'there can be situations where BOOT schemes are good deals for both government and private sector'.

9 The proportion of total infrastructure investments provided by private finance arrangements is unclear in developed countries, but estimates include Pollitt's figure above of 15-20 per cent of the UK capital budget, an earlier figure of about 10-13 per cent (HM Treasury 2003:128) and Pollitt's remark that this proportion is as high as 50 per cent in sectors such as transport. 
${ }^{10}$ National Audit Office (2003) surveys also reported positive feedback from 81 per cent of organisational personnel who saw PFI projects as 'excellent' (6 per cent), 'good' (46 per cent) or 'okay' (29 per cent).

${ }^{11}$ Note that we also ought to keep our analysis of the commercial outcomes for government separate from our assessment of the policy-delivery mechanism here. The terms on which this hospital was transferred back to government after the 'political failure' would presumably need to be known before we assessed the relative overall success of the subsequent commercial transaction to the taxpayer.

12 A recent example of this concern was the bidding for the Melbourne 'EastLink' project. This 39km motorway was cited as being a \$2.5 billion project, and the 39-year concession was awarded after bids were made by two consortia, both of whom were owned by the same parent company.

${ }^{13}$ Such scepticism of policy promises seems broadly consistent with the evaluation evidence presented here. Much of the above value-for-money evaluation evidence has, as well, unfortunately been based on business case projections rather than real measurements of cash flows.

14 See, for example, Hodge (2004b:241), who notes that after independent power producers were contracted to build greater capacity, an increase of more than 200 per cent occurred in the 'purchased power adjustment' - an additional charge remitted to private power producers for unused power. Moreover, while overall electricity bills had almost doubled, power prices were double those in neighbouring countries such as Thailand and Malaysia. This situation understandably led to outrage in the Philippines.

15 See, for instance, The Economist (2002).

${ }^{16}$ Feedback to this effect resulted in the development of a 'public interest test' within the department's guidance material, which - if the boxes are ticked - guarantees (at least in terms of advocating bureaucrats) that the public interest has been 'defined' and met.

17 Public Accounts and Estimates Committee 2006, Seventy-First Report to the Parliament, Report on Private Investment in Public Infrastructure; and Public Accounts Committee 2006, Inquiry into Public Private Partnerships.

18 See Joint Select Committee on the Cross City Tunnel, First Report, XI, NSW Parliament. 